\title{
Evaluation partial substitution of fresh forage with silage on dairy milk production in Kunak which added palm kernel meal and Gracilaria sp on daily feed
}

\author{
Agustin Herliatika*1), Idat Galih permana ${ }^{2)}$ and Despal ${ }^{2)}$ \\ 1) Indonesian Research Institute for Animal Production \\ ${ }^{2)}$ Department of Nutrition and Feed Science, Faculty of Animal Science, Postgraduate \\ School, IPB University, Kampus IPB, Jl. Agatis, Babakan, Kec. Dramaga, Bogor, Jawa \\ Barat, Indonesia, 16680
}

Submitted: 04 November 2019, Accepted: 03 September 2020

\begin{abstract}
Kunak is the biggest community for a traditional dairy cattle farmer in West of Java. Providing good qualities and quantities of forage continuously in a year for ruminants, still be one problem in this community caused by different forage production between the dry season and rainy season. High forage production in the rainy season could be stored as silage to provide forage requirement in the dry season. These research examined in 2 experiments. The first experiment aimed to determine the effect partial-substitute of fresh forage uses grass silage on the quantities and qualities of daily milk production. The second experiment aimed to determine the quantities and qualities of dairy cattle milk production, affected by adding Gracilaria sp (GS) on partial-substitute of fresh forage uses grass silage and palm kernel-meal (S-PKM) on daily feed. These research uses complete randomized design divided into two treatments (to substitute as much as $0 \%$ and $10.08 \%$ Dry matter of fresh forage with grass silage) with five replications on the first experiment and three treatments $(0 \% \mathrm{~S}-\mathrm{PKM}-0 \% \mathrm{GS}$; $19.51 \% \mathrm{~S}-\mathrm{PKM}-0 \% \mathrm{GS} ; 15.03 \% \mathrm{~S}-\mathrm{PKM}-2.03 \% \mathrm{GS}$ ) with three replications on the second experiment. The results showed that substituting as much as $10.08 \% \mathrm{DM}$ of fresh forage uses grass silage does not affect the feed intake (11.56-11.98 Kg DM/head/day), Feed Digestibility (59.37-63.45\%), milk protein-production $(0.36-0.37 \mathrm{Kg} / \mathrm{head} /$ day), milk fat-production (0.54$0.58 \mathrm{Kg} / \mathrm{head} /$ day), daily milk production $(12.36-12.67 \mathrm{Kg} / \mathrm{head} /$ day) in the first experiment. Feed intake (Kg DM /head/day), milk protein-production ( $\mathrm{Kg} / \mathrm{head} /$ day), milk fat-production $(\mathrm{Kg} / \mathrm{head} /$ day $)$, and daily milk production $(\mathrm{Kg} / \mathrm{head} /$ day) increase with added $15.03 \% \mathrm{~S}-\mathrm{PKM}-$ $2.03 \% \mathrm{GS}$ in the second experiment.
\end{abstract}

Keywords: Gracilaria s; Palm kernel-meal; Seaweed; Silage

*Corresponding Author: tikaagustinherlia@gmail.com 


\section{INTRODUCTION}

Kunak is the biggest community for a traditional dairy cattle farmer in West of Java. Different conditions between rain and dry season in Tropics caused a problem to provide enough good quality forage continuously in a year. Forage will rotten in rain season caused by high intensity of rain which makes base part of forage trapped into a puddle, but enough water needed for forage growth not available when the dry season comes.

This condition showed that forage storage technology needed to solve those problems. There are many kinds of forage storage technology, such as hay, haylage, and silage. Hay and haylage have disadvantages if compared with silage. Provitamin A contents on hay or haylage are lower than silage, and sensitivity Provitamin A causes this during the drying process. Coppa et al. (2011) explained that $\beta$-carotene content on pasture forage decreases in the form of hay which is proved by the red-yellow colour of cheese produced from dairy cattle which feeding use hay and concentrate will decrease when compared with dairy cattle which feeding in a pasture. Palm kernel meal is one of the cheap feedstuff with a high content of protein, but information about application this stuff in dairy cattle ration is limited.

This condition encourages us to evaluate the application of this stuff in dairy cattle ration. Gracilaria $s p$ is seaweed which produces on a big scale. High ash contents on this stuff identified that seaweed could use as minerals source. This stuff has uses in one of commercial industry and believed can increase milk production, but broad information about the effect of this stuff to increasing milk production still needed.

\section{MATERIALS AND METHODS Research Design}

These research were conducted in Kunak using complete randomized design and examined in 2 experiments. Ten Frisian
Holstein $(431.20 \pm 59.92 \mathrm{Kg})$, The day in milk between 90-360 days, parity number between 3-5 for the first experiment which consisted two treatments $(0 \%$ grass silage and $10.08 \%$ grass silage) with five replications for six weeks (the first week for adaptation and the last week for collecting data). Nine Frisian Holstein (404.87 \pm 28.74 $\mathrm{Kg}$ ), the day in milk between 90 to 300 days, parity number between 1-4 for the second experiment which consisted three treatments $(0 \% \mathrm{~S}-\mathrm{PKM}-0 \% \mathrm{GS} ; 19.51 \% \mathrm{~S}$ PKM-0\%GS; $15.03 \%$ S-PKM-2.03\%GS) with three replications for six weeks (the first week for adaptation and the last week for collecting data).

\section{Silage Preparation}

Elephant grass chopped approximately $3 \mathrm{~cm}$ using chopper machine. Molasses were added as much as $2 \%$ from the wet weight of elephant grass. PKM was added on silage in the second experiment (Elephant grass: PKM is 70.61:29.39). Both single elephant grass or mixture with PKM loads into a drum which added PKM in the base of the drum to absorb excess water production during ensilage process. Those silages were stored ( $\geq 2$ weeks) in anaerobic condition.

\section{Fleigh Score}

Fleigh score measured use Indikut et al. (2009) to determine the silage quality depends on $\mathrm{pH}$ and dry matter (DM) of silage. This measure used to predict the shelf life of silage. Formula to calculate Fleigh score is:

$$
\mathrm{FS}=220+(2 \times \mathrm{DM}(\%)-15)-(40 \times \mathrm{pH})
$$

\section{Feed Formulation}

Feedstuffs used in these experiments were analyzed proximate compositions (AOAC 2005) in Laboratorium Pusat Penelitian Sumberdaya Hayati dan Teknologi IPB then formulated depends on feed nutritions which give daily in Kunak. Feed formulation for these researches showed in Table 1. 
Milk Production and Qualities Measurement

Milk production was measured every day in the last week. Qualities of milk were measured using Lactoscan S Milk Analyzer by Milko Tronic Ltd

\section{Manure Scoring}

Manure score before and after the comparison of treatments to evaluate digestibility of new feed formulation. Manure score depends on high of fresh manure, colour, sound when falling, texture and particles left after water washing.

\section{In Vitro Digestibility}

Measurement of in vitro digestibility used Tilley and Terry (1963) method. Formula to calculate dry matter digestibility after incubation is

$$
\frac{\text { DM Sample }-(\text { DM Residue }- \text { DM Blanko of Rumen })}{\text { DM Sample }} \times 100 \%
$$

Formula to calculate organics matter digestibility after incubation is:

$$
\frac{\text { Organics matter of Sample-(DM Residue- Ash Residue) }}{\text { Organics matter (OM) of the sample }} \times 100 \%
$$

Table 1. Feed formulation in the first and the second experiment

\begin{tabular}{lrrrrr} 
& \multicolumn{3}{c}{ Experiment 1 } & \multicolumn{3}{c}{ Experiment 2 } \\
\cline { 2 - 6 } & \multicolumn{1}{c}{ R0 } & \multicolumn{1}{c}{ R1 } & R0 & R1 & R2 \\
\hline Feedstuffs (\%) & & & & & \\
Elephant grass silage & 0.00 & 10.08 & 0.00 & 0.00 & 0.00 \\
Gracilaria sp & 0.00 & 0.00 & 0.00 & 0.00 & 2.03 \\
Elephant grass silage + PKM & 0.00 & 0.00 & 0.00 & 19.51 & 15.03 \\
Tofu dregs & 25.18 & 25.90 & 39.39 & 37.77 & 40.11 \\
Concentrate & 34.27 & 34.67 & 16.95 & 16.33 & 17.37 \\
Grass land & 30.34 & 21.54 & 0.00 & 0.00 & 0.00 \\
Elephant grass & 10.21 & 7.80 & 28.55 & 21.52 & 18.92 \\
Paddy straw & 0.00 & 0.00 & 15.11 & 4.87 & 6.54 \\
Nutrient composition (\%) & & & & & \\
Dry Matter (DM) & 40.42 & 39.52 & 30.06 & 28.39 & 30.32 \\
Ash & 8.53 & 9.17 & 9.74 & 9.05 & 9.75 \\
Crude protein (CP) & 10.86 & 11.33 & 14.20 & 14.79 & 14.55 \\
Ether extract (EE) & 5.12 & 5.32 & 5.44 & 5.29 & 5.41 \\
Crude fiber (CF) & 12.95 & 15.26 & 21.99 & 21.77 & 21.53 \\
Total Digestibility Nutreint (TDN) & 79.00 & 76.66 & 70.06 & 70.47 & 70.17 \\
\hline
\end{tabular}

\section{Volatile Fatty Acid and $\mathrm{NH}_{3}$}

VFA (Volatile Fatty acids) measured use Steam Distillation Methode (General Laboratory Procedure, 1966). $\mathrm{NH}_{3}$ (ammonia) measured use Conway (1957).

\section{Data Analysis}

Data of feed intake and feed characteristics were analyzed use ANOVA (Analysis of Variance) and compared with average different on experiment 1 and
Tukey HSD on experiment 2. Data of silage production and qualities were analyzed use ANOVA and compared with average different.

Data of dairy cattle performances were analyzed use ANCOVA (Analysis of Covariance) and compared with average different on experiment 1 and Sidak Test or Contrast Test. All data analyzed at $\alpha=0.05$ in SPSS 16.0. 


\section{RESULT AND DISCUSSION}

This research produces elephant grass silage with and without PKM. The result from both silages production shows that both silages have good physical and ensilage quality. Total of spoilage in this research is lower than another study in Brazil. Silage production in Brazil which uses banker with double plastics layer, according to Bernardes dan do Rego (2014) will cut $1 / 4,1 / 2,3 / 4$, and all silage as much $32.3 \%$, $18.8 \%, 19.6 \%$, and $29.2 \%$ respectively, caused by spoilage. This research showed that not more than $1 / 4$ (Table 2) silage cut caused by spoilage which depends on the uses the drum for ensilage process, so the stability of anaerobic condition could hold longer than uses double-layer plastics. Single grass Silage $\mathrm{pH}$ on this research is lower than mixture grass and PKM silage which probably due to different fibre structures between grass and PKM. $\% \mathrm{NDF}$ and \% ADF on elephant grass are both $44.00 \%$ DM and $27.40 \%$ DM, respectively (Ajayi 2011), whereas on palm kernel 78.40\%BK and 53.40\%BK respectively Wyngaard, Meeske, and Erasmus (2005).

Table 2. Silage production and quality

\begin{tabular}{|c|c|c|}
\hline Parameters & Elephant grass silage & Elephant grass silage $+\mathrm{PKM}$ \\
\hline \multicolumn{3}{|l|}{ Physical quality } \\
\hline Weight of load $(\mathrm{Kg})$ & $67.73 \pm 3.14$ & $90.33 \pm 2.86$ \\
\hline Weight of unload $(\mathrm{Kg})$ & $67.43 \pm 1.77$ & $92.82 \pm 3.63$ \\
\hline Colour & Yellowish green & Dark yellowish-green \\
\hline Odour & Acid & Weak acid \\
\hline Spoilage $(\%)$ & $0.00-11.11$ & 0.00 \\
\hline \multicolumn{3}{|l|}{ Ensilage quality } \\
\hline $\mathrm{pH}$ & $3.75 \pm 0.32 b$ & $4.50 \pm 0.08 \mathrm{a}$ \\
\hline OM degradation (\%) & $7.80 \pm 3.50 b$ & $46.24 \pm 2.78 \mathrm{a}$ \\
\hline $\mathrm{CP}$ degradation $(\%)$ & $29.59 \pm 2.67 b$ & $45.12 \pm 2.75 \mathrm{a}$ \\
\hline Fleigh Score & $86.20 \pm 12.84 a$ & $69.60 \pm 3.27 b$ \\
\hline \multicolumn{3}{|l|}{ Utility } \\
\hline \multicolumn{3}{|l|}{ Fermentability in rumen } \\
\hline $\mathrm{N}-\mathrm{NH}_{3}(\mathrm{mM})$ & $10.71 \pm 2.29 b$ & $14 . .51 \pm 1.11 \mathrm{a}$ \\
\hline Total VFA (mM/gr BK) & $134.22 \pm 22.80$ & $112.69 \pm 21.09$ \\
\hline \multicolumn{3}{|l|}{ Digestibility $(\%)$} \\
\hline Dry matter & $44.61 \pm 7.31$ & $51.00 \pm 6.51$ \\
\hline Organics matter & $99.39 \pm 0.10$ & $99.49 \pm 0.12$ \\
\hline
\end{tabular}

Different letters show significant differences between columns (ANOVA with $\alpha=5 \%$ ) in the same row

The higher NDF and ADF contents on palm kernel than elephant grass caused palm kernel more challenging to digest by microorganisms during ensilage process, so acids produced by microorganisms lower on the mixture of grass and PKM silage and final $\mathrm{pH}$ on this silage would higher than single grass silage. $\mathrm{pH}$ value for corn silages in Normandy, Prancis are 4 or 3.8 according to Richard et al. (2009), 4.8 for grass silage according to Van Gastelen et al. (2015), 46.67 for grass silages according to Ali et al. (2014) and 4.3 for grass silage according to Rego et al. (2008). pH values for two kinds silage uses in this research showed a normal level according to some literature before. Added 2\% molasses on silages process could decrease silages $\mathrm{pH}$ rapidly. Li $\mathrm{M}$ et al. (2014) showed that $\mathrm{pH}$ of elephant grass silage is 4.64 , whereas added $2 \%$ molasses 
on ensilages process could decreasing $\mathrm{pH}$ silage until 4.35. Protein degradation (\%) on ramie leaves $(\mathrm{DM}=18 \%)$ silages which supplemented with cassava meal, pollard and coarse grinding corn (targeting DM mixture $=32 \%$ ) were $28.10 \%, 20.50 \%$ and $23.80 \%$ respectively, but on ramie leaves $(\mathrm{DM}=11.4 \%)$ silages which supplemented with cassava meal, pollard and corn (targeting DM mixture $=32 \%$ ) were $15.42 \%$, $3.93 \%$ and $4.73 \%$ respectively (Despal et al 2011). VFA (mM) on ramie leaves silages which supplemented with cassava-meal, pollard and corn were 127.70, 164.20 and 135.00 respectively, and $\mathrm{N}-\mathrm{NH}_{3}(\mathrm{mM})$ were 13.2, 19.4 and 11.2 respectively (Despal et al . 2011). Single grass silage and mixture grass and PKM silage showed that VFA and $\mathrm{N}-\mathrm{NH}_{3}$ contents (Table 2) were closed to literature. Definition of fleigh scores is 85 $100 \%, 60-80 \%, 55-60 \%, 25-40 \%$, and $<20 \%$ are outstanding quality, good quality, moderate quality, satisfying quality and worthless, respectively Indikut et al. (2009).

Table 3. Nutrient consumption and ration fermentability

\begin{tabular}{lccccc}
\hline \multirow{2}{*}{$\begin{array}{c}\text { Nutrient intake } \\
\text { (kg/head/day) }\end{array}$} & \multicolumn{2}{c}{ Experiment $1^{*}$} & \multicolumn{3}{c}{ Experiment $2^{+}$} \\
\cline { 2 - 6 } DM & $11.98 \pm 0.58$ & $11.56 \pm 0.03$ & $11.64 \pm 0.21 \mathrm{~b}$ & $11.29 \pm 0.61 \mathrm{~b}$ & $14.45 \pm 0.00 \mathrm{a}$ \\
$\mathrm{Ash}$ & $1.02 \pm 0.05$ & $1.06 \pm 0.00$ & $1.12 \pm 0.04 \mathrm{~b}$ & $1.01 \pm 0.04 \mathrm{~b}$ & $1.40 \pm 0.00 \mathrm{a}$ \\
$\mathrm{CP}$ & $1.31 \pm 0.05$ & $1.33 \pm 0.00$ & $1.66 \pm 0.06 \mathrm{~b}$ & $1.68 \pm 0.10 \mathrm{~b}$ & $2.10 \pm 0.00 \mathrm{a}$ \\
$\mathrm{EE}$ & $0.63 \pm 0.03$ & $0.65 \pm 0.00$ & $0.64 \pm 0.04 \mathrm{~b}$ & $0.60 \pm 0.05 \mathrm{~b}$ & $0.79 \pm 0.00 \mathrm{a}$ \\
$\mathrm{CF}$ & $1.55 \pm 0.05 \mathrm{~b}$ & $1.79 \pm 0.00 \mathrm{a}$ & $2.54 \pm 0.05 \mathrm{~b}$ & $2.44 \pm 0.10 \mathrm{~b}$ & $3.08 \pm 0.00 \mathrm{a}$ \\
$\mathrm{TDN}$ & $9.47 \pm 0.48 \mathrm{a}$ & $8.85 \pm 0.03 \mathrm{~b}$ & $8.18 \pm 0.27 \mathrm{~b}$ & $7.97 \pm 0.48 \mathrm{~b}$ & $10.17 \pm 0.00 \mathrm{a}$ \\
Fermentability & & & & & \\
N-NH $(\mathrm{mM})$ & $6.83 \pm 0.97$ & $7.18 \pm 1.28$ & $7.85 \pm 0.92$ & $8.91 \pm 1.19$ & $9.34 \pm 1.46$ \\
Total VFA & & & & & \\
(mM/gr DM) & $138.91 \pm 16.30$ & $152.77 \pm 12.91$ & $148.26 \pm 8.42$ & $121.70 \pm 27.07$ & $132.43 \pm 22.43$ \\
Digestibility $(\%)$ & & & & & \\
Dry matter & $63.45 \pm 8.59$ & $59.37 \pm 6.62$ & $60.94 \pm 5.53$ & $66.15 \pm 5.57$ & $67.73 \pm 5.96$ \\
Organics matter & $99.57 \pm 0.08$ & $99.53 \pm 0.11$ & $99.54 \pm 0.09$ & $99.59 \pm 0.10$ & $99.60 \pm 0.08$ \\
\hline
\end{tabular}

Different letters show significant differences between columns (ANOVA with $\alpha=5 \%$ ) in the same row; *advanced test use average different ${ }^{+}$advanced test use Tukey HSD

Single grass silage quality is excellent, whereas the quality of mixture-silage of grass and PKM is good (Table 2). This value uses to predicted lifetime storage of silage. Silage with a high value of FS to be predicted has long-lifetime storage than the low one. Percentage of PKM uses in R1 dan $\mathrm{R} 2$ experiment $2(5.73 \%$ and $4.42 \% \mathrm{DM}$ respectively) is present on the tolerant level. According to Wyngaard, Meeske, Erasmus (2005), feeding 0-40\% DM PKM for Jersey does not show significant differences on feed intake, milk production, qualities of milk (fat, protein, and lactose), so does with feeding 0-15\% DM PKM for Holstein (Carvalho et al. 2006). This research showed that feeding PKM in level 5.73\% and $4.42 \%$ DM could improve feed digestibility (non-significant on in vitro test (Table 3), but could increasing manure score on in vivo (Table 4).

Meanwhile, increasing manure score could be identified as a negative effect of added PKM in daily feed. High NDF (Neutral Detergent Fiber) and ADF (Acid Detergent Fiber) contents in PKM could be the reason for low digestibility of feed. Those contents make more feed passed digest tract as faeces, and texture faeces formed more solid than before, so manure score increasing. However, milk production and qualities $(\mathrm{Kg} / \mathrm{head} /$ day $)$ showed the positive effect with added PKM (Table 4), so a negative assessment about added PKM 
in daily feed could be ignored. There is no different body weight and BCS before and after treatment (Table 4). It is identified that feed formulation uses (Table 1) in these researches could accomplishing all nutrients required for dairy cattle which used in these researches. Milk contents and production in experiment 1 showed no significant different value, whereas added $4.42 \% \mathrm{DM}$ PKM and seaweed in experiment 2 could improved milk production and qualities (Kg/head/day).

Table 4. Dairy cattle performances

\begin{tabular}{|c|c|c|c|c|c|}
\hline \multirow{2}{*}{ Parameters } & \multicolumn{2}{|c|}{ Experiment 1} & \multicolumn{3}{|c|}{ Experiment 2} \\
\hline & R0 & R1 & R0 & R1 & R2 \\
\hline \multicolumn{6}{|l|}{ Manure score } \\
\hline Before treatment & $2.21 \pm 0.39$ & $2.30 \pm 0.18$ & $2.57 \pm 0.37$ & $2.31 \pm 0.70$ & $2.35 \pm 0.17$ \\
\hline After treatment & $2.70 \pm 0.18$ & $2.66 \pm 0.12$ & $2.06 \pm 0.10^{\mathrm{b}}$ & $2.39 \pm 0.10^{\mathrm{a}}$ & $2.35 \pm 0.11^{\mathrm{a}}$ \\
\hline \multicolumn{6}{|l|}{ Bodyweight } \\
\hline Before treatment & $413.34 \pm 30.59$ & $396.39 \pm 27.27$ & $444.14 \pm 93.81$ & $444.35 \pm 38.06$ & $405.10 \pm 50.79$ \\
\hline After treatment & $430.60 \pm 31.25$ & $411.41 \pm 16.43$ & $444.38 \pm 97.50$ & $457.04 \pm 37.05$ & $415.93 \pm 53.14$ \\
\hline \multicolumn{6}{|c|}{ BCS (Body Condition Score) } \\
\hline Before treatment & $3.20 \pm 0.45$ & $3.00 \pm 0.00$ & $3.33 \pm 0.58$ & $3.00 \pm 0.00$ & $3.00 \pm 0.00$ \\
\hline After treatment & $3.20 \pm 0.45$ & $3.00 \pm 0.00$ & $3.33 \pm 0.58$ & $3.00 \pm 0.00$ & $3.00 \pm 0.00$ \\
\hline $\begin{array}{l}\text { Milk Production } \\
\text { (Kg/head/day) }\end{array}$ & $12.36 \pm 2.59$ & $12.67 \pm 2.50$ & $7.67 \pm 2.25 \mathrm{~b}^{\mathrm{b}}$ & $10.07 \pm 0.59 \mathrm{ab}^{\mathrm{ab}}$ & $13.81 \pm 1.35 \mathrm{a}^{\mathrm{a}}$ \\
\hline \multirow[t]{2}{*}{ Parameters } & \multicolumn{2}{|c|}{ Experiment 1} & \multicolumn{3}{|c|}{ Experiment 2} \\
\hline & R0 & $\mathrm{R} 1$ & R0 & R1 & $\mathrm{R} 2$ \\
\hline \multicolumn{6}{|c|}{ Milk contents (Kg/head/day) } \\
\hline Fat & $0.54 \pm 0.14$ & $0.58 \pm 0.07$ & $0.35 \pm 0.09^{b}$ & $0.52 \pm 0.11^{\mathrm{b}}$ & $0.68 \pm 0.02^{\mathrm{a}}$ \\
\hline Protein & $0.36 \pm 0.07$ & $0.37 \pm 0.06$ & $0.22 \pm 0.07^{\mathrm{b}}$ & $0.30 \pm 0.03^{\mathrm{ab}}$ & $0.41 \pm 0.03^{\mathrm{a}}$ \\
\hline Lactose & $0.53 \pm 0.10$ & $0.55 \pm 0.09$ & $0.32 \pm 0.10^{\mathrm{b}}$ & $0.45 \pm 0.05^{\mathrm{ab}}$ & $0.61 \pm 0.04^{\mathrm{a}}$ \\
\hline $\begin{array}{l}\text { SNF } \\
\text { (Solid Non Fat) }\end{array}$ & $0.96 \pm 0.18$ & $1.00 \pm 0.16$ & $0.58 \pm 0.18^{\mathrm{b}}$ & $0.81 \pm 0.08^{\mathrm{ab}}$ & $1.10 \pm 0.08^{\mathrm{a}}$ \\
\hline Salt & $0.08 \pm 0.01$ & $0.08 \pm 0.01$ & $0.05 \pm 0.01 b^{b}$ & $0.07 \pm 0.01 \mathrm{ab}^{\mathrm{b}}$ & $0.09 \pm 0.01 \mathrm{a}^{\mathrm{a}}$ \\
\hline Total Solid & $1.49 \pm 0.30$ & $1.57 \pm 022$ & $0.93 \pm 0.27^{b}$ & $1.33 \pm 0.19^{\mathrm{ab}}$ & $1.78 \pm 0.10^{\mathrm{a}}$ \\
\hline Density (Kg/L) & $1.028 \pm 0.001$ & $1.028 \pm 0.001$ & $1.027 \pm 0.002$ & $1.028 \pm 0.001$ & $1.038 \pm 0.001$ \\
\hline $\begin{array}{l}\text { Milk Production } \\
\text { (Liter/head/day) } \\
\text { Milk contents }(\%)\end{array}$ & $12.18 \pm 2.18$ & $12.78 \pm 2.44$ & $7.47 \pm 2.19 b^{b}$ & $9.80 \pm 0.56 \mathrm{ab}^{\mathrm{ab}}$ & $13.44 \pm 1.32 \mathrm{a}^{\mathrm{a}}$ \\
\hline Fat & $4.35 \pm 0.69$ & $4.64 \pm 0.57$ & $4.62 \pm 0.53$ & $5.12 \pm 0.84$ & $4.98 \pm 0.47$ \\
\hline Protein & $2.89 \pm 0.09$ & $2.93 \pm 0.14$ & $2.83 \pm 0.21$ & $3.00 \pm 0.14$ & $2.96 \pm 0.11$ \\
\hline Lactose & $4.31 \pm 0.14$ & $4.37 \pm 0.21$ & $4.22 \pm 0.31$ & $4.46 \pm 0.20$ & $4.40 \pm 0.17$ \\
\hline $\begin{array}{l}\text { SNF } \\
\text { (Solid Non Fat) }\end{array}$ & $7.79 \pm 0.25$ & $7.91 \pm 0.37$ & $7.64 \pm 0.56$ & $8.07 \pm 0.36$ & $7.97 \pm 0.30$ \\
\hline Salt & $0.65 \pm 0.02$ & $0.66 \pm 0.03$ & $0.64 \pm 0.05$ & $0.67 \pm 0.03$ & $0.67 \pm 0.03$ \\
\hline Total Solid & $11.75 \pm 0.70$ & $12.54 \pm 0.89$ & $12.26 \pm 1.07$ & $13.19 \pm 1.19$ & $12.95 \pm 0.76$ \\
\hline $\begin{array}{l}\text { - } \quad \text { Differen } \\
\text { in the sa } \\
\text { - } \quad \text { Supersc } \\
\text { the sam }\end{array}$ & $\begin{array}{l}\text { tters show si } \\
\text { row with ad } \\
\text { show a sign }\end{array}$ & $\begin{array}{l}\text { ificant differe } \\
\text { iced test use } \\
\text { ant differenc }\end{array}$ & $\begin{array}{l}\text { es between c } \\
\text { lak test. } \\
\text { between colu }\end{array}$ & $\begin{array}{l}\text { umns (ANOV } \\
\text { ns (ANOVA }\end{array}$ & $\begin{array}{l}\text { with } \alpha=5 \% \text { ) } \\
\text { ith } \alpha=5 \% \text { ) in }\end{array}$ \\
\hline
\end{tabular}


Milk qualities (\%) on R2 does not change because increasing milk contents (Kg/head/day) followed by increasing milk production, so the relative probability of milk qualities (\%) still constant. R1 in experiment 2 showed no significant difference in milk production and qualities but tended to increase (Table 4).

\section{CONCLUSIONS}

Partial-substitute of $10,08 \%$ DM grass silage could use to manage enough supplies of good-quality forage for dairy cattle in Kunak without changing the performance of dairy cattle. Adding palm kernel meal and seaweed in grass silage in partial-substitute of fresh forage could improve the performance of dairy cattle (milk production and qualities).

\section{REFERENCES}

Ajayi, F. T. (2011). Effects of feeding ensiled mixtures of elephant grass (Pennisetum purpureum) with three grain legume plants on digestibility and nitrogen balance of West African Dwarf goats. Livestock Science, 142(1-3), 80-84. https://doi.org/10. 1016/j.livsci.2011.06.020

Ali, M., Cone, J. W., Van Duinkerken, G., Klop, A., Kruisdijk, J., Blok, M. C., Bruinenberg, M., \& Hendriks, W. H. (2014). Relationship between chemical composition and in situ rumen degradation characteristics of grass silages in dairy cows. NJAS Wageningen Journal of Life Sciences, 70-71, 9-15. https://doi.org/10.1016/ j.njas.2014.01.002

AOAC. (2005). Official Methods of Analysis of AOAC International (W. Horwitz, G. W, \& Latimer (eds.); 18th ed.). AOAC International.

Bernardes, T. F., \& do Rêgo, A. C. (2014). Study on the practices of silage production and utilization on Brazilian dairy farms. Journal of Dairy Science, 97(3), 1852-1861. https://doi.org/10. 3168/jds.2013-7181

Carvalho, L. P. F., Cabrita, A. R. J.,
Dewhurst, R. J., Vicente, T. E. J., Lopes, Z. M. C., \& Fonseca, A. J. M. (2006). Evaluation of Palm Kernel Meal and Corn Distillers Grains in Corn Silage-Based Diets for Lactating Dairy Cows. Journal of Dairy Science, 89(7), 2705-2715. https://doi.org/10. 3168/jds.S0022-0302(06)72346-3

Conway, E. J. (1957). Microdiffusion of Analysis of Association Official Analytical Chemist. Georgia Press.

Coppa, M., Verdier-Metz, I., Ferlay, A., Pradel, P., Didienne, R., Farruggia, A., Montel, M. C., \& Martin, B. (2011). Effect of different grazing systems on upland pastures compared with hay diet on cheese sensory properties evaluated at different ripening times. International Dairy Journal, 21(10), 815-822. https://doi.org/10.1016/j.ida iryj.2011.04.006

Despal, D., Permana, I. G., Safarina, S. N., \& Tatra, A. J. (2011). Penggunaan berbagai sumber karbohidrat terlarut air untuk meningkatkan kualitas silase daun rami. Media Peternakan, 34(1), 69-76. https://doi.org/10.5398/medpe t.2011.34.1.69

General Laboratory Procedure. (1966). Department of Dairy Science. The University of Wisconsin.

Idukut, L., Arikan, B. A., Kaplan, M., Guven, I., Atalay, A. I., \& Kamalak, A. (2009). Potential nutritive value of sweet corn as a silage crop with or without corn Ear. Journal of Animal and Veterinary Advances, 8(4), 734-741.

Li, M., Zi, X., Zhou, H., Hou, G., \& Cai, Y. (2014). Effects of sucrose, glucose, molasses and cellulase on fermentation quality and in vitro gas production of king grass silage. Animal Feed Science and Technology, 197, 206-212. https://doi.org/10.1016 /j.anifeedsci.2014.06.016

Rego, O. A., Regalo, S. M. M., Rosa, H. J. D., Alves, S. P., Borba, A. E. S., Bessa, R. J. B., Cabrita, A. R. J., \& Fonseca, A. J. M. (2008). Effects of Grass Silage and Soybean Meal 
Supplementation on Milk Production and Milk Fatty Acid Profiles of Grazing Dairy Cows. Journal of Dairy Science, 91(7), 2736-2743. https://doi .org/10.3168/jds.2007-0786

Richard, E., Heutte, N., Bouchart, V., \& Garon, D. (2009). Evaluation of fungal contamination and mycotoxin production in maize silage. Animal Feed Science and Technology, 148(24), 309-320. https://doi.org/10.1016/ j.anifeedsci.2008.02.004

Tilley, J. M. A., \& Terry, R. A. (1963). A two-stage technique for the in vitro digestion of forage crops. Grass and Forage Science, 18(2), 104-111. https://doi.org/10.1111/j.1365-2494.1 963.tb00335.x

Van Gastelen, S., Antunes-Fernandes, E. C.,
Hettinga, K. A., Klop, G., Alferink, S. J. J., Hendriks, W. H., \& Dijkstra, J. (2015). Enteric methane production, rumen volatile fatty acid concentrations, and milk fatty acid composition in lactating HolsteinFriesian cows fed grass silage- or corn silage-based diets. Journal of Dairy Science, 98(3), 1915-1927. https:// doi.org/10.3168/jds.2014-8552

Van Wyngaard, J. D. V., Meeske, R., \& Erasmus, L. J. (2015). Effect of palm kernel expeller as supplementation on production performance of Jersey cows grazing kikuyu-ryegrass pasture. Animal Feed Science and Technology, 199, 29-40. https://doi.org/10.1016/ j.anifeedsci.2014.10.017 